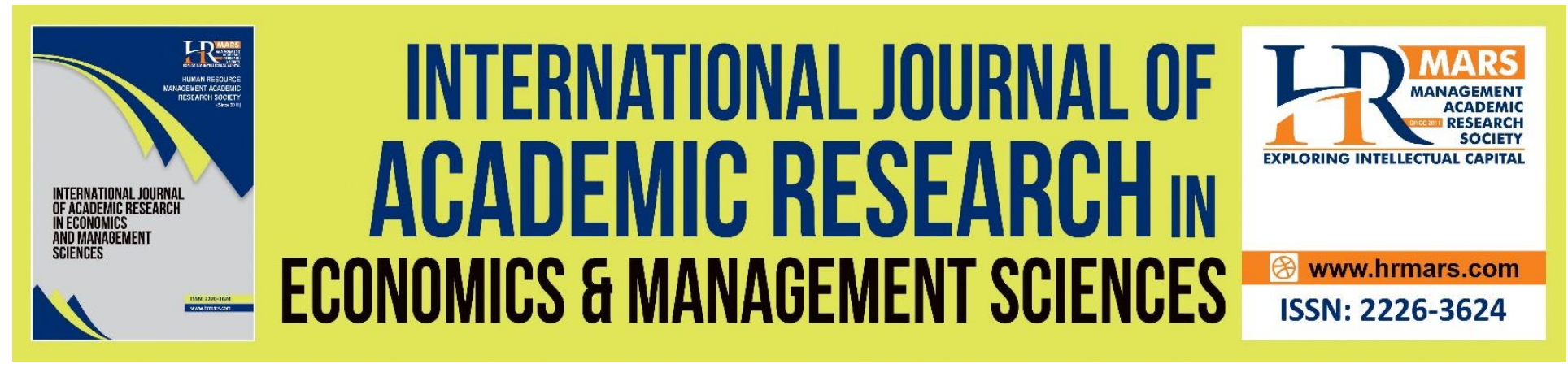

\title{
Decomposing Perceived Behavioural Control: Addressing Financial Literacy in Determining Muslims' Intention to Purchase Unsought Products
}

Nurul Farhana Nasir, Rosmimah Mohd Roslin, Muhammad Nur Firdaus Nasir, Muhammad Faiz Nasir, Muhammad Arif Nasir, Nor Aizan Mohamed

To Link this Article: http://dx.doi.org/10.6007/IJAREMS/v10-i1/8927

DOI:10.6007/IJAREMS/v10-i1/8927

Received: 05 January 2021, Revised: 29 January 2021, Accepted: 20 February 2021

Published Online: 21 March 2021

In-Text Citation: (Nasir et al., 2021)

To Cite this Article: Nasir, N. F., Roslin, R. M., Nasir, M. N. F., Nasir, M. F., Nasir, M. A., \& Mohamed, N. A. (2021).

Decomposing Perceived Behavioural Control: Addressing Financial Literacy in Determining Muslims'

Intention to Purchase Unsought Products. International Journal of Academic Research in Economics and Managment and Sciences, 10(1), 1-19.

Copyright: (C) 2021 The Author(s)

Published by Human Resource Management Academic Research Society (www.hrmars.com)

This article is published under the Creative Commons Attribution (CC BY 4.0) license. Anyone may reproduce, distribute, translate and create derivative works of this article (for both commercial and non-commercial purposes), subject to full attribution to the original publication and authors. The full terms of this license may be seen

at: http://creativecommons.org/licences/by/4.0/legalcode

Vol. 10, No. 1, 2021, Pg. 1 - 19

http://hrmars.com/index.php/pages/detail/IJAREMS

JOURNAL HOMEPAGE

Full Terms \& Conditions of access and use can be found at

http://hrmars.com/index.php/pages/detail/publication-ethics 


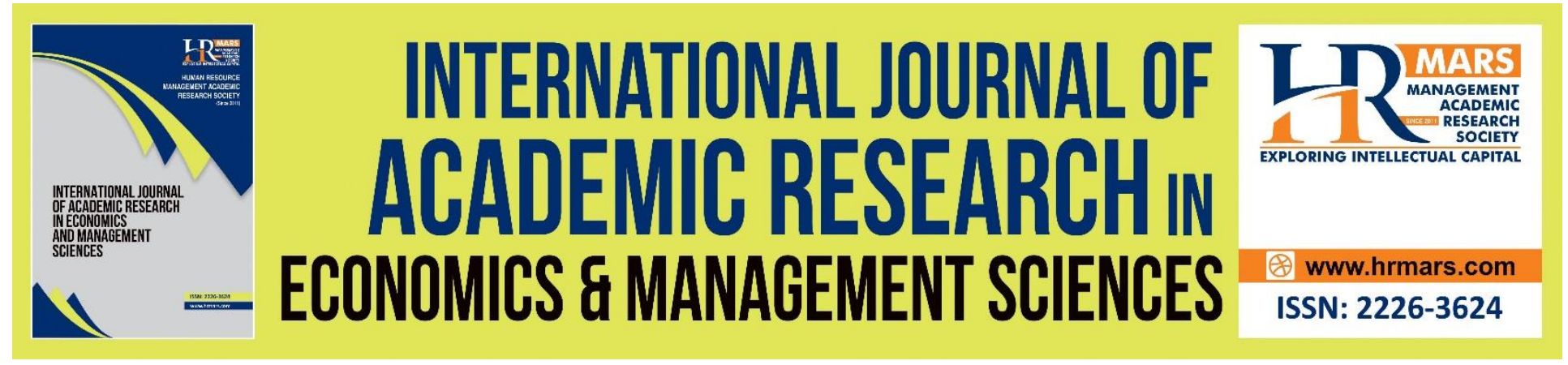

\title{
Decomposing Perceived Behavioural Control: Addressing Financial Literacy in Determining Muslims' Intention to Purchase Unsought Products
}

\section{Nurul Farhana Nasira, Rosmimah Mohd Roslin ${ }^{\mathrm{b}}$, Muhammad Nur Firdaus Nasirc , Muhammad Faiz Nasird, Muhammad Arif Nasire, Nor Aizan Mohamed ${ }^{f}$}

${ }^{a}$ Faculty of Business Management, Universiti Teknologi MARA Melaka, Malaysia, ${ }^{\mathrm{b}}$ Arshad Ayub Graduate Business School, Universiti Teknologi MARA Shah Alam, Malaysia, 'Faculty of Art and

Design, Universiti Teknologi MARA Melaka, Malaysia, ${ }^{\mathrm{d}}$ Faculty of Business Management, Universiti Teknologi MARA Shah Alam, Malaysia, eFaculty of Hospitality and Tourism, Kolej Universiti Islam Melaka, Malaysia, ${ }^{\mathrm{f}}$ Faculty of Business Management, Universiti Teknologi MARA Melaka, Malaysia

\begin{abstract}
Purpose: This paper addresses the importance of planning for unanticipated risks which may lead to losses in peoples' lives and in this study, the lives of Muslim consumers when they are not managing unanticipated risks well. The need to purchase unsought products like life insurance/Takaful dictates the relevance of financial literacy in affecting perceived behavioural control that may influence purchase intention.

Design/methodology/approach: This study uses Structural Equation Modelling as means of assessing the proposed framework. Using the Decomposed Theory of Planned Behaviour (DTPB) as the basis, this paper examines the relevance of determinants affecting perceived behavioural control in influencing purchase intention of unsought goods with financial literacy as a new determinant in the DTPB framework.

Findings: The findings reveal that financial literacy, resource facilitating condition and selfefficacy affect perceived behavioural control which ultimately influence purchase intention.

Practical implications: By examining financial literacy, resource facilitating condition and selfefficacy on perceived behavioural control, the study validated the importance of these constructs in affecting consumers' perceived behavioural control and purchase intention. This study would be useful to life insurance operators, as the findings can be inputs for the formulation and implementation of promotional strategies for life insurance/Takaful.

Originality/value: This study provides insights for the inclusion of financial literacy as one of the determinants in the decomposition of perceived behavioural control.
\end{abstract}


Keywords: Perceived Behavioural Control, Unsought Goods, Decomposed Theory of Planned Behavior, Purchase Intention

\section{Introduction}

People living in this world is constantly exposed to risks and often these are likely to lead to unanticipated losses. Risks are uncertainties of outcomes in given situations and it is difficult to anticipate. Past decades have shown how natural disasters and disease outbreaks have led to catastrophic outcomes including sickness, loss of properties, financial losses, and even loss of lives. Although human beings are continually exposed to numerous risks, such losses are sometimes unexpected. At present, the world is suffering from the outbreak of the coronavirus (COVID-19) which is seriously impacting the global economy and has an effect on religion, education, and social psychology (Megatsari et al., 2020). The impact of this pandemic brought about by this virus is affecting many industries including that of tourism, aviation, hospitality businesses, and entertainment (Mustafa and Bagul, 2020). Coronavirus is continuing to spread and has killed millions of people around the world and many countries are struggling to free themselves from this pandemic. Even though the fatality rate of Covid-19 is still being assessed, it is apparent that the global effect is devastating economies and has severe social implications (Kaligis et al., 2020). Many countries in the world are focused on reducing the Covid-19 spread by implementing restrictions of public movement and sometimes total lockdown. These comprehensive restrictions are enforced to prevent the spread of the virus by limiting the movements of people. As such, social distancing has become the norm in people's everyday lives and therefore has restricted the interactions of people in communities. It is this form of restriction that can be related to the Islamic views on the handling of pandemics as stated by the Al-Quran and Hadith, or the words of the Prophet Mohammad SAW (PBUH). In essence, the Islamic views on plagues or diseases that are widespread are as stated below,

"When you hear that a plague is in a land, do not enter it and if the plague breaks out in a place while you are in it, do not leave that place"

(Narrated by Sahih Muslim)

"Do not place a sick patient with a healthy person"

(Narrated by Sahih Muslim)

"Indeed, Allah loves those who turn to Him (repenting) and he loves those who keep themselves clean and pure"

(Surah Al-Baqarah, 2: 223)

Based on the current situation that befalls this world, it is clearly observed that everyone is exposed to risks. As mentioned by Abdullah and Rashid (2014), risks affect lives and can cause death. In essence, the level of risks is determined by the lifestyles and socio-economic conditions of the communities (Dom et al., 2016). Therefore, the need to take precautionary actions towards the possibility of unexpected risks is expected of everyone. Essentially, the concept of 'ikhtiar' or initiative and 'tawakal', meaning the full reliance and trust in God's plans are embedded in the lives of Muslims. On this note, Islam instills upon Muslims to take precautions against risks, which 
is termed as 'ikhtiar' (Sukiman, 2017; Ghoni, 2016; Matsawali et al., 2012). Ikhtiar is an effort to minimize the possibility of the negative outcome of the risks. The concept of 'tawakal' that is to surrender to Allah occurs after efforts have been exhausted by people ('ikhtiar') (Prasetyo and Absori, 2018; Zakub, Widodo, and Setiawan, 2018). Basically, the concept of 'tawakal' has always been misunderstood (Aksa, 2020). Islam prohibits Muslims to surrender without taking any effort. For instance, as the head of a household, a husband is responsible for the welfare of his dependents. He must ensure that he provides sufficient food, clothing, shelter, and other basic needs to his family. As the breadwinner of the family, a husband should ensure that he provides sufficient assets to his wife and children to ensure that they are well provided for upon his death. This is important to ensure the sustainability of the family. This responsibility must be carried out diligently as stated in the Al-Quran and al-Hadith,

"And give you increase in wealth and children, and bestow on your gardens and bestow on you rivers"

(Surah Nuh, 71:12)

"When a Muslim spends something on his family intending to receive Allah's reward it is regarded as Sadaqa for him"

(Narrated by Sahih Bukhari)

"You will be rewarded for whatever you spend for Allah's sake even if it were a morsel which you put in your wife's mouth"

(Narrated by Sahih Bukhari)

One effective way to minimize risks is by mitigating them and transferring them to another responsible party. Insurance is a risk financing method that transfers the financial consequences to another party. Both parties agree to share the risks through the contractual agreement stipulated in the contract. By transferring the risks to another party, the insured (the person who is taking the insurance) is giving another party that is the insurer (insurance company) the responsibility to protect himself against unforeseen risks. By purchasing life insurance or Takaful for Muslims, a husband can make sure that the dependents he leaves behind are well taken care of financially. Undoubtedly, the sudden loss of a husband as a sole breadwinner will be traumatic to the dependents who may suffer emotional and financial losses. The family stands to lose the primary source of income in the family. Therefore, life insurance/Takaful plays an important role as the buffer to protect the family as this may reduce the impact of financial losses arising because of such unfortunate events.

From the marketing perspective, life insurance is an unsought product that may need more effort and well-planned strategies to induce purchase. Unsought products are products that people are unaware of and do not directly recognize as beneficial. The realization of needs may only occur when disasters strike or when aggressive sales representatives approach them to buy the products. Even though there are various forms of protection in the market offered by insurers, there are still many who do not understand and may not have insurance or Takaful protection (Daljit, 2011). As much as Islam dictates the need to plan and protect the family's well- 
being in the face of unprecedented occurrences, many Muslims have yet to have any form of insurance or Takaful protection.

Based on the theoretical perspective, past studies have used the Decomposed Theory of Planned Behaviour to explain the behavioral intention of consumers towards specific purchases (Taylor and Todd, 1995). Even though the Decomposed Theory of Planned Behaviour was first introduced to explain purchase intention within the information technology settings, this theory can be applied in different contextual settings (Kanimozhi and Sundar, 2017; Susanto and Goodwin, 2013; Leejoeiwara, 2013; Santos and Okazaki, 2013; Susanto, 2013; Atsoglou and Jimoyiannis, 2012; Lau, 2011; Macredie and Mijinyawa, 2011). The relevancy of this theory to be adapted as the framework in determining the intention to purchase unsought products like life insurance/Takaful is established in past studies (Nasir, Roslin, and Chui, 2017).

The Decomposed Theory of Planned Behaviour is chosen as a framework in this conceptual paper due to the explanatory power of the theory as it integrates the Theory of Reasoned Action (TRA) and the Theory of Planned Behavior (TPB) (Ajzen, 1991). This is because the decomposition of each construct in the Decomposed Theory of Planned Behaviour as applied in the framework indicates a more comprehensive model to understand purchase intention. Basically, Taylor and Todd (1995) decomposed perceived behavioral control based on the three elements of selfefficacy, resource facilitating elements, and technology facilitating condition. However, due to the different nature or contextual settings, this paper seeks to propose the adoption of only two determinants, that is self-efficacy and resource facilitating conditions, and added a new determinant that is financial literacy in the context of purchasing unsought products among Muslims.

This paper is focused on unsought products, specifically life insurance/Takaful among Muslims as the basis of Islam has already dictated the need to manage in the event of unprecedented events. As such, it is interesting to note such preparedness among Muslim consumers. Muslims are chosen as the subject matter of this study as there is insufficient information in past studies in regards to Muslims' purchase behaviour, therefore the investigation of Muslims' intention to purchase life insurance/Takaful is meaningful in adding to the body of knowledge in this area of consumer behaviour. In addition, this paper discusses the role of financial literacy as one of the decompositions in the perceived behavioural control construct. This study is set on the decomposition elements where technology facilitating conditions from the established DTPB is dropped from the proposed framework as one of the decomposing element. This paper therefore attempts to discuss relevant literature in one of the constructs of Decomposed Theory of Planned Behaviour, that is perceived behavioural control and its decompositions (i.e resource facilitating conditions, self-efficacy, and financial literacy) among Muslims who are already guided by the principles of mitigating risks.

\section{Literature Review}

Perceived behavioural control towards intention to purchase unsought products

One of the determinants in behavioural intention is perceived behavioural control. Perceived behavioural control refers to the perception of people whether it is difficult or otherwise in performing specific behaviour. People will tend to perform a behaviour if he/she feels that it is easy to do so. In contrast, it is difficult for people to perform behaviours perceived as complicated. The level of individual's performance of the behaviour is important and will 
significantly influence such behaviour (Ajzen, 1991). The tendency of people to perform specific behaviour is high if they are equipped with sufficient resources (Madden, Ellen and Ajzen, 1992). Conversely, the tendency of people to perform behaviour is low if they are not equipped with sufficient resources.

Perceived behavioural control is one of the important factors in explaining the variance of intentions. Taylor and Todd (1995) decomposed perceived behavioural control into three, that is self-efficacy, resource facilitating condtion, and technology facilitating condition. Past literature have shown the significant effect of perceived behavioural control on intention (Kanimozhi and Sundar, 2017; Khasawneh and Irshaidat, 2017; Pratiwi and Hartoyo, 2014; Echchabi and Echchabi, 2013; Innan and Moustaghfir, 2012). Specifically, Kanimozhi and Sundar (2017) conducted a study on the adoption of $4 \mathrm{G}$ mobile services in India and found perceived behavioural control to positively influence behavioural intention.

In another perspective, a study by Khasawneh and Irshaidat (2017) examined consumer behaviour in relation to the applications of mobile banking. They found that perceived behavioural control had significant effect on behavioural intention. In relation to this, the study by Pratiwi and Hartoyo (2014) had shown that perceived behavioural control significantly affect intention to purchase life insurance. The study investigates the intention to purchase life insurance among university students in Indonesia. On a similar note, a study by Echchabi and Echchabi (2013) examined the willingness to purchase Takaful among Muslims in France. They found that perceived behavioural control significantly influence intention to purchase Takaful. Selectively, another study by Innan and Moustaghfir (2012) had shown that there is significant effect of perceived behavioural control towards intention. The study explored behavioural intention among employees in Morocco. Based on the above studies, it can be postulated that perceived behavioural control do play an important role in determining behavioural intention. It is therefore an important construct in determining purchase intention.

\section{Decomposition of perceived behavioural control construct (i.e. resource facilitating condition,} self-efficacy, and financial literacy)

The original Decomposed Theory of Planned Behavior decomposed perceived behavioural control into three determinants, that is resource facilitating conditions, self-efficacy, and technology facilitating condition. However due to the different contextual settings, only two determinants are adopted in this paper. These determinants are resource facilitating conditions and self-efficacy but the third determinant of perceived behavioural control is included in the context of the purchase of unsought goods which is financial literacy. As such, this paper proposes the inclusion of financial literacy when studying the relevance of unsought goods in determining purchase intention.

Resource facilitating conditions refer to the availability of sufficient resources to perform the task. There must be factors to encourage the person to perform specific tasks. These factors refer to money, time, and resources (Triandis, 1980). In fact, when people are equipped with such factors (i.e. money, time, resources), they are willing to perform such behaviour because they feel the ease of executing them. Bandura (1986) introduced the self-efficacy concept. This concept explains the ability of people to perform the behaviour. It is difficult for them to perform the behavior if they are not equipped with such factors (i.e. money, time, resources). The effect of resource facilitating condition and self-efficacy on perceived behavioural control has been 
validated in numerous past studies (Aziz, Husin, and Hussin, 2017; Primabodi and Samopa, 2017; Susanto, 2013). A conceptual paper by Aziz et al. (2017) explained that resource facilitating conditions and self-efficacy are significant determinants of the intention to purchase a family Takaful. Primabodi and Samopa (2017) found resource facilitating conditions and self-efficacy to positively and significantly affect perceived behavioural control. Meanwhile, Susanto (2013) in his conceptual paper on determining individual acceptance of electronic government services found a similar result. Resource facilitating conditions and self-efficacy both significantly influence behavioural intention through perceived behavioural control.

In reference to financial literacy, it is understood as the ability of the person to accumulate their wealth properly based on specific knowledge (Mahdzan and Victorian, 2013). Past studies have documented the effect of financial literacy on behavioural intention (Nasir, Roslin, and Chui, 2020; Nasir et al., 2017; Omar, 2007). The conceptual paper by Nasir et al. (2020) clarifies that the important determinants of financial literacy are people who are good in financial knowledge as they are likely to purchase life insurance. Additionally, Nasir et al. (2017) explained that insufficient knowledge and lack of confidence were two reasons for low consumption of life insurance/Takaful. Another study by Omar (2007) in investigating the behaviour towards insurance found that lack of financial literacy is the main reason why Nigerians refused to purchase insurance. People who are low in financial literacy will tend to make wrong decisions in managing their assets and wealth. Based on the above arguments, it is established that resource facilitating condition, self-efficacy, and financial literacy are three determinants in perceived behavioural control.

\section{Framework and Hypotheses Development}

Based on the literature, the research framework for this study proposes an extension of the perceived behavioural control construct as conveyed by TRA, TPB, and DTPB to include financial literacy. The research framework proposed for this study is shown in Figure 1.

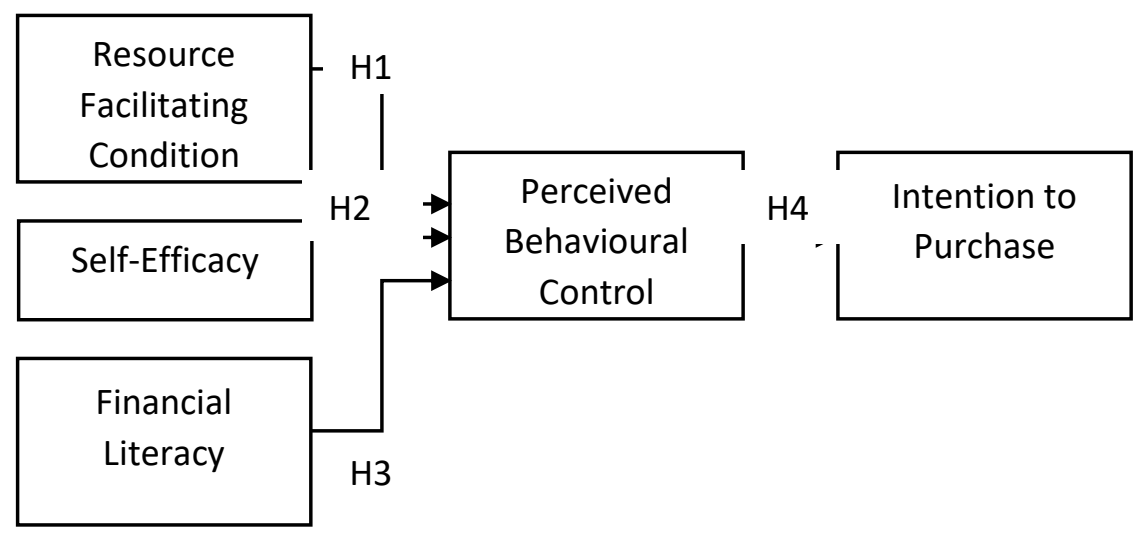

Figure 1. Framework

Four hypotheses are formulated in this study as follows:

H1: Resource facilitating condition affects perceived behavioural control

H2: Self-efficacy affects perceived behavioural control 
INTERNATIONAL JOURNAL OF ACADEMIC RESEARCH ECONOMICS AND MANAGEMENT SCIENCES Vol. 10 , No. 1, 2021, E-ISSN: 2226-3624 ㄷ 2021 HRMARS

H3: Financial literacy affects perceived behavioural control

H4: Perceived behavioural control influences intention to purchase unsought products

It is postulated that apart from resource facilitating condition and self-efficacy, financial literacy is an important determinant to an individual's perceived behavioural control. Those with knowledge on the financial situation surrounding their purchase potential are more likely to be in control of their key decisions. Financial literacy allows for the ease in the potential of executing a decision and as such is postulated to be of importance in the context of deciding on unsought goods purchase. In this context, the decision to buy or otherwise life insurance or Takful would very much depend on the amount of financial information and critical implications a person has.

\section{Research Methods}

Sampling

This study used purposive sampling as a means of identifying relevant respondents. The selected respondents are Muslims with the potential of purchasing life insurance/Takaful. This sampling technique was chosen due to the short time frame and better response rate attained and it is the most practical method to reach the target respondents. Specifically, convenience sampling technique like purposive sampling is commonly used in behavioural intention studies (Alalwan, 2020; Ahmad et al., 2020; Akgunduz, Bardakoglu, and Koba, 2020; Ghorbanzade, Mehrani, and Rahehagh, 2019; Oladapo, Omar, Muda, and Abdurraheem, 2019; Husin, Ismail, and Rahman, 2016; Husin and Rahman, 2016; Alharbi and Drew, 2014; Mtebe and Raisamo, 2014; Tsai, 2012). The target populations of this study are Muslims in six cities in the Klang Valley. The questionnaires were distributed to Muslims who have not purchased life insurance or Takaful in the Klang Valley, thus, this is the purposive nature of the selection. In this study, Klang Valley is chosen due to the population concentration of this region in Malaysia and according to Husin et al. (2016), Klang Valley has the major metropolitan cities in Malaysia.

\section{Measure and questionnaire development}

A self-administered questionnaire was developed to measure the research constructs (i.e. perceived behavioural control, resource facilitating condition, self-efficacy, financial literacy, and purchase intention). Apart from measuring the research constructs in this study, the researcher has also incorporated specific demographic characteristics of the respondents in the questionnaire. The questionnaire begins with Section $A$ that addresses the demographic profiles. In the second section of the questionnaire (i.e. Section B), respondents were asked to answer questions pertaining to their degree of agreement on specific perceived behavioural control, resource facilitating condition, self-efficacy, financial literacy, and intention measures. The statements in the questionnaire essentially measure the effect of resource facilitating condition (FR), self-efficacy (GE), and financial literacy (HF) toward perceived behavioural control (PBC) and behaviour intention (ITP). This study employs a seven-point Likert-scale. Partial least square (PLS) was then used to evaluate the measurement and structural model as recommended by Hair, Ringle, and Sarstedt (2011). The construct used to measure resource-facilitating condition was adapted from Bhattacherjee (2000) and Khalid and John (2008) while those used to measure selfefficacy were adapted from Qader and Zainuddin (2011) and Khalid and John (2008). The construct used to measure financial literacy are adapted from Potrich, Vieira, and Mendes-Da- 
Silva (2016), and Ahmad, Simun, and Masuod (2006) and finally, the construct to measure purchase intention was adapted from Husin et al. (2016), Khan and Azam (2016) and Lada, Tanakinjal, and Amin (2009).

\section{Sample Characteristics}

A total of 316 usable questionnaires were eventually attained. The respondents were potential life insurance/Takaful buyers in the Klang Valley who were intercepted conveniently at their workplaces. The majority of the respondents were females making up 62.70 percent while the remaining 37.30 percent were males. Additionally, 10.1 percent of the respondents were below 20 years of age, 47.2 percent were from the 20 to 30 years age category, 23.4 percent from 31 to 40 years old, 10.4 percent between 41 to 50 years old, while the remaining 8.9 percent were above 50 years old. As for the highest education level, a majority of the respondents possessed degrees (61.7 percent), followed by those with a diploma that is 15.2 percent, SPM holders made up 12.7 percent, masters degree were 7 percent, other qualification made up 2.2 percent, and the remaining of 1.3 percent were PhD holders. About 47.5 percent of the respondents worked in the public sector, while the remaining 52.5 percent of the respondents worked in the private sector. As for their individual monthly income, 23.4 percent of the respondents were having less than RM1000 per month, 24.1 percent generated incomes between RM1000 to RM3000, 27.5 percent had RM3001 to RM5000 income level, 17.4 percent of the respondents generated income between RM5001 to RM7000, the remaining of the respondents (7.6 percent) had an income of more than RM7000. The profile of respondents is summarized in Table 1. 
INTERNATIONAL JOURNAL OF ACADEMIC RESEARCH ECONOMICS AND MANAGEMENT SCIENCES Vol. 10, No. 1, 2021, E-ISSN: 2226-3624 (C) 2021 HRMARS

Table 1. Respondents Profile

\begin{tabular}{|c|c|c|c|c|}
\hline Variables & Details & $\begin{array}{l}\text { Frequency } \\
(\mathrm{N}=316)\end{array}$ & $\begin{array}{c}\text { Percentage } \\
\text { (\%) }\end{array}$ & $\begin{array}{l}\text { Cumulative } \\
\text { Percentage } \\
(\%)\end{array}$ \\
\hline \multirow[t]{2}{*}{ Gender } & Male & 118 & 37.30 & 37.30 \\
\hline & Female & 198 & 62.70 & 100.00 \\
\hline \multirow[t]{5}{*}{ Age } & Below 20 years old & 32 & 10.10 & 10.10 \\
\hline & $20-30$ years old & 149 & 47.20 & 57.30 \\
\hline & $31-40$ years old & 74 & 23.40 & 80.70 \\
\hline & $41-50$ years old & 33 & 10.40 & 91.10 \\
\hline & Above 50 years old & 28 & 8.90 & 100.00 \\
\hline Highest & SPM & 40 & 12.70 & 12.70 \\
\hline Education & Diploma & 48 & 15.20 & 27.80 \\
\hline \multirow[t]{4}{*}{ Level } & Degree & 195 & 61.70 & 89.60 \\
\hline & Master & 22 & 7.00 & 96.50 \\
\hline & PhD & 4 & 1.30 & 97.80 \\
\hline & Others & 7 & 2.20 & 100.00 \\
\hline Occupation & Public & 150 & 47.50 & 47.50 \\
\hline Sector & $\begin{array}{l}\text { Servant } \\
\text { Private Sector }\end{array}$ & 166 & 52.50 & 100.00 \\
\hline Individual & Less & 74 & 23.40 & 23.40 \\
\hline Monthly & $\mathrm{RM} 1,000$ & 76 & 24.10 & 47.50 \\
\hline \multirow[t]{8}{*}{ Income } & $\mathrm{RM} 1,000$ & 87 & 27.50 & 75.00 \\
\hline & $\mathrm{RM} 3,000$ & 55 & 17.40 & 92.40 \\
\hline & $\mathrm{RM} 3,001$ & 24 & 7.60 & 100.00 \\
\hline & $\mathrm{RM} 5,000$ & & & \\
\hline & RM5,001 & & & \\
\hline & $\mathrm{RM7,000}$ & & & \\
\hline & More & & & \\
\hline & $\mathrm{RM7}, 000$ & & & \\
\hline
\end{tabular}

\section{Results and Data Analysis}

Measurement Model

In assessing the measurement model, the researcher used convergent validity (loading), composite reliability, average variance extracted (AVE), and discriminant validity as means of evaluating. All of these assessments were confirmed by the PLS algorithm. Based on Table 2, the factor loadings for all constructs exceeded the 0.60 thresholds. A value of 0.60 thresholds and above is needed to assess factor loadings as suggested by Chin (1998). All the AVE values were higher than the suggested value of 0.50 . Meanwhile, all the values for composite reliability were higher than the suggested value of 0.70 . 
INTERNATIONAL JOURNAL OF ACADEMIC RESEARCH ECONOMICS AND MANAGEMENT SCIENCES Vol. 10, No. 1, 2021, E-ISSN: 2226-3624 @ 2021 HRMARS

Table 2. Factors Loadings and reliability

\begin{tabular}{|c|c|c|c|c|c|}
\hline Construct & Items & Loading & $\begin{array}{l}\text { Composite } \\
\text { Reliability } \\
\text { (CR) }\end{array}$ & $\begin{array}{c}\text { Average } \\
\text { Variance } \\
\text { Extracted } \\
\text { (AVE) }\end{array}$ & $\begin{array}{c}\text { Convergent } \\
\text { Validity (AVE > } \\
0.5)\end{array}$ \\
\hline \multirow{8}{*}{$\begin{array}{l}\text { Perceived } \\
\text { Behavioural } \\
\text { Control }\end{array}$} & PBC1 & 0.835 & \multirow[t]{8}{*}{0.936} & \multirow[t]{8}{*}{0.647} & \multirow[t]{8}{*}{ YES } \\
\hline & PBC2 & 0.861 & & & \\
\hline & PBC3 & 0.798 & & & \\
\hline & PBC4 & 0.829 & & & \\
\hline & PBC5 & 0.616 & & & \\
\hline & PBC6 & 0.825 & & & \\
\hline & PBC7 & 0.791 & & & \\
\hline & PBC8 & 0.854 & & & \\
\hline \multirow{5}{*}{$\begin{array}{l}\text { Resource } \\
\text { Facilitating } \\
\text { Condition }\end{array}$} & FR1 & 0.792 & \multirow[t]{5}{*}{0.921} & \multirow[t]{5}{*}{0.702} & \multirow[t]{5}{*}{ YES } \\
\hline & FR2 & 0.698 & & & \\
\hline & FR3 & 0.902 & & & \\
\hline & FR4 & 0.907 & & & \\
\hline & FR5 & 0.871 & & & \\
\hline \multirow[t]{6}{*}{ Self-Efficacy } & GE1 & 0.760 & \multirow[t]{6}{*}{0.918} & \multirow[t]{6}{*}{0.651} & \multirow[t]{6}{*}{ YES } \\
\hline & GE2 & 0.770 & & & \\
\hline & GE3 & 0.851 & & & \\
\hline & GE4 & 0.799 & & & \\
\hline & GE5 & 0.797 & & & \\
\hline & GE6 & 0.860 & & & \\
\hline \multirow{9}{*}{$\begin{array}{l}\text { Financial } \\
\text { Literacy }\end{array}$} & HF1 & 0.651 & \multirow[t]{9}{*}{0.905} & \multirow[t]{9}{*}{0.515} & \multirow[t]{9}{*}{ YES } \\
\hline & $\mathrm{HF} 2$ & 0.728 & & & \\
\hline & HF3 & 0.734 & & & \\
\hline & HF4 & 0.733 & & & \\
\hline & HF5 & 0.730 & & & \\
\hline & HF6 & 0.771 & & & \\
\hline & HF7 & 0.683 & & & \\
\hline & HF8 & 0.703 & & & \\
\hline & HF9 & 0.721 & & & \\
\hline \multirow{8}{*}{$\begin{array}{l}\text { Intention to } \\
\text { Purchase }\end{array}$} & ITP1 & 0.821 & \multirow[t]{8}{*}{0.969} & \multirow[t]{8}{*}{0.795} & \multirow[t]{8}{*}{ YES } \\
\hline & ITP2 & 0.897 & & & \\
\hline & ITP3 & 0.919 & & & \\
\hline & ITP4 & 0.914 & & & \\
\hline & ITP5 & 0.888 & & & \\
\hline & ITP6 & 0.874 & & & \\
\hline & ITP7 & 0.911 & & & \\
\hline & ITP8 & 0.902 & & & \\
\hline
\end{tabular}


INTERNATIONAL JOURNAL OF ACADEMIC RESEARCH ECONOMICS AND MANAGEMENT SCIENCES Vol. 10 , No. 1, 2021, E-ISSN: 2226-3624 ㄷ 2021 HRMARS

To assess discriminant validity, the researcher used cross-loadings, Fornell-larcker criterion, and heterotrait-monotrait ratio of correlations (HTMT) as shown in Table 3, Table 4, and Table 5 respectively. Cross-loadings is the first criterion to be examined in discriminant validity. Table 3 shows the cross-loadings. To assess cross-loadings, an indicator outer loadings on a construct must be higher compared to its cross-loadings with other constructs. Therefore, based on Table 3, cross-loading criteria were met in this study.

Table 3. Cross-Loadings

\begin{tabular}{|c|c|c|c|c|c|}
\hline Construct & $\begin{array}{c}\text { Financial } \\
\text { Literacy }\end{array}$ & ITP & PBC & $\begin{array}{l}\text { Resource } \\
\text { facilitating } \\
\text { condition }\end{array}$ & $\begin{array}{c}\text { Self- } \\
\text { efficacy }\end{array}$ \\
\hline FR1 & 0.330 & 0.387 & 0.533 & 0.792 & 0.502 \\
\hline FR2 & 0.173 & 0.209 & 0.314 & 0.698 & 0.305 \\
\hline FR3 & 0.248 & 0.370 & 0.466 & 0.902 & 0.467 \\
\hline FR4 & 0.213 & 0.353 & 0.454 & 0.907 & 0.471 \\
\hline FR5 & 0.237 & 0.405 & 0.491 & 0.871 & 0.487 \\
\hline GE1 & 0.253 & 0.612 & 0.591 & 0.395 & 0.760 \\
\hline GE2 & 0.191 & 0.396 & 0.484 & 0.367 & 0.770 \\
\hline GE3 & 0.264 & 0.536 & 0.632 & 0.487 & 0.851 \\
\hline GE4 & 0.170 & 0.521 & 0.538 & 0.470 & 0.799 \\
\hline GE5 & 0.183 & 0.476 & 0.592 & 0.432 & 0.797 \\
\hline GE6 & 0.251 & 0.593 & 0.658 & 0.472 & 0.860 \\
\hline HF1 & 0.651 & 0.164 & 0.274 & 0.287 & 0.224 \\
\hline HF2 & 0.728 & 0.269 & 0.270 & 0.187 & 0.211 \\
\hline HF3 & 0.734 & 0.262 & 0.285 & 0.211 & 0.199 \\
\hline HF4 & 0.733 & 0.279 & 0.272 & 0.173 & 0.191 \\
\hline HF5 & 0.730 & 0.114 & 0.232 & 0.196 & 0.175 \\
\hline HF6 & 0.771 & 0.144 & 0.238 & 0.202 & 0.198 \\
\hline HF7 & 0.683 & 0.137 & 0.314 & 0.287 & 0.231 \\
\hline HF8 & 0.703 & 0.128 & 0.194 & 0.144 & 0.156 \\
\hline HF9 & 0.721 & 0.169 & 0.220 & 0.162 & 0.149 \\
\hline ITP1 & 0.265 & 0.821 & 0.718 & 0.375 & 0.583 \\
\hline ITP2 & 0.258 & 0.897 & 0.740 & 0.429 & 0.616 \\
\hline ITP3 & 0.258 & 0.919 & 0.701 & 0.355 & 0.580 \\
\hline ITP4 & 0.250 & 0.914 & 0.693 & 0.339 & 0.572 \\
\hline ITP5 & 0.200 & 0.888 & 0.675 & 0.369 & 0.586 \\
\hline ITP6 & 0.146 & 0.874 & 0.634 & 0.355 & 0.569 \\
\hline ITP7 & 0.276 & 0.911 & 0.688 & 0.401 & 0.579 \\
\hline ITP8 & 0.215 & 0.902 & 0.657 & 0.385 & 0.558 \\
\hline PBC1 & 0.221 & 0.724 & 0.835 & 0.366 & 0.667 \\
\hline PBC2 & 0.321 & 0.701 & 0.861 & 0.466 & 0.621 \\
\hline PBC3 & 0.173 & 0.661 & 0.798 & 0.439 & 0.579 \\
\hline
\end{tabular}


INTERNATIONAL JOURNAL OF ACADEMIC RESEARCH ECONOMICS AND MANAGEMENT SCIENCES Vol. 10, No. 1, 2021, E-ISSN: 2226-3624 ㄷ 2021 HRMARS

\begin{tabular}{|l|l|l|l|l|l|}
\hline PBC4 & 0.323 & 0.624 & $\mathbf{0 . 8 2 9}$ & 0.533 & 0.600 \\
\hline PBC5 & 0.363 & 0.423 & $\mathbf{0 . 6 1 6}$ & 0.348 & 0.302 \\
\hline PBC6 & 0.370 & 0.589 & $\mathbf{0 . 8 2 5}$ & 0.481 & 0.603 \\
\hline PBC7 & 0.253 & 0.533 & $\mathbf{0 . 7 9 1}$ & 0.435 & 0.587 \\
\hline PBC8 & 0.355 & 0.672 & $\mathbf{0 . 8 5 4}$ & 0.473 & 0.643 \\
\hline
\end{tabular}

Fornell-Larcker is the second criterion to examine discriminant validity. Based on Table 4, the Fornell-Larcker requirement was met in this study when there were no cross-loadings greater than the respective loadings.

Table 4. Fornell-Larcker Criterion

\begin{tabular}{|c|c|c|c|c|c|}
\hline Construct & $\begin{array}{c}\text { Financial } \\
\text { Literacy }\end{array}$ & ITP & PBC & $\begin{array}{l}\text { Resource } \\
\text { facilitating } \\
\text { condition }\end{array}$ & $\begin{array}{c}\text { Self- } \\
\text { efficacy }\end{array}$ \\
\hline $\begin{array}{l}\text { Financial } \\
\text { Literacy }\end{array}$ & 0.718 & & & & \\
\hline ITP & 0.264 & 0.891 & & & \\
\hline PBC & 0.364 & 0.774 & 0.805 & & \\
\hline $\begin{array}{l}\text { Resource } \\
\text { facilitating } \\
\text { condition }\end{array}$ & 0.294 & 0.423 & 0.551 & 0.838 & \\
\hline Self-efficacy & 0.274 & 0.652 & 0.727 & 0.544 & 0.807 \\
\hline
\end{tabular}

The third criterion to assess discriminant validity is by assessing the Heterotrait-Monotrait Ratio of Correlations (HTMT). Based on Table 5, all the values for the Heterotrait-Monotrait Ratio of Correlations (HTMT) were less than a value of 0.90 as suggested by Teo, Srivastava, and Jiang (2008). Therefore, the Heterotrait-Monotrait of Correlations (HTMT) requirement was met in this study. The results from all these tables indicate that discriminant validity was established in this study. Hence, there was no issue of multi-collinearity. Therefore, the next step of assessing the structural model was conducted.

Table 5. Heterotrait-Monotrait Ratio of Correlations (HTMT) Criterion

\begin{tabular}{|c|c|c|c|c|c|}
\hline Construct & $\begin{array}{c}\text { Financial } \\
\text { Literacy }\end{array}$ & ITP & PBC & $\begin{array}{c}\text { Resource } \\
\text { facilitating } \\
\text { condition }\end{array}$ & $\begin{array}{c}\text { Self- } \\
\text { efficacy }\end{array}$ \\
\hline $\begin{array}{c}\text { Financial } \\
\text { Literacy }\end{array}$ & & & & & \\
\hline ITP & 0.278 & & & & \\
\hline PBC & 0.403 & 0.813 & & & \\
\hline $\begin{array}{c}\text { Resource } \\
\text { facilitating } \\
\text { condition }\end{array}$ & 0.315 & 0.445 & 0.597 & & \\
\hline Self-efficacy & 0.299 & 0.698 & 0.786 & 0.597 & \\
\hline
\end{tabular}




\section{Structural Model}

In assessing the structural model, a 5000-bootstrap re-sampling of data was conducted to test all the hypotheses (Hair, Hult, Ringle, and Sarstedt, 2017). The assessment of the structural model to evaluate the predictive power of the model and to analyze relationships among latent constructs proposed in this study were conducted. The results of the structural model are shown in Table 6 and Figure 2. The predictive power of the model is evaluated by using the R-square value $\left(R^{2}\right)$. Additionally, to assess the strength of the relationship, path coefficients were used. The $R$-square value $\left(R^{2}\right)$ for the variance in the dependent variable i.e. perceived behavioural control towards participation in life insurance or Takaful $\left(R^{2}=0.582\right)$; and intention $\left(R^{2}=0.599\right)$. The $R^{2}$ of 0.582 indicates that 58.2 percent of the variation in perceived behavioural control can be explained by resource facilitating condition, self-efficacy, and financial literacy. Meanwhile, $\mathrm{R}^{2}$ of 0.599 indicates that 59.9 percent of the variation in intention can be explained by perceived behavioural control. The effect size $\left(f^{2}\right)$ was assessed as suggested by Cohen (1998). Based on Table 6, two relationships, (perceived behavioural control -> intention) and (self-efficacy -> perceived behavioural control) were found to have a large effect size $\left(f^{2}\right)$. However, two relationships (resource facilitating condition $\rightarrow$ perceived behavioral control) and (financial literacy $\rightarrow$ perceived behavioural control) were found to have small effect sizes $\left(f^{2}\right)$. After calculating the effect size, the predictive relevance of the model $\left(Q^{2}\right)$ was evaluated In this study, the predictive relevance of the model is greater than 0 , thus, indicating that the model has predictive relevance as suggested by Chin (2010). The results showed that all hypotheses are supported. $\mathrm{H} 1, \mathrm{H} 2, \mathrm{H} 3$, and $\mathrm{H} 4$ examined the influence of perceived behavioural control, resource facilitating condition, self-efficacy, financial literacy on intention to participate in the life insurance or Takaful. Specifically, results revealed that all the relationships were statistically significant: perceived behavioural control $(\beta=0.774, p<0.01, t=30.193)$, resource facilitating condition $(\beta=0.190, p<0.01, t=3.627)$, self-efficacy $(\beta=0.583, p<0.01, t=11.374)$, financial literacy $(\beta=0.148, p<0.01, t=3.407)$. As such, it is concluded that all of the hypotheses are statistically significant in this study.

Figure 2. SEM Path Analysis generated by Smart PLS 
INTERNATIONAL JOURNAL OF ACADEMIC RESEARCH ECONOMICS AND MANAGEMENT SCIENCES Vol. 10, No. 1, 2021, E-ISSN: 2226-3624 C 2021 HRMARS

Table 6. Empirical Results

\begin{tabular}{|c|c|c|c|c|c|c|c|c|}
\hline $\begin{array}{l}\text { Hypothe } \\
\text { sis }\end{array}$ & $\begin{array}{c}\text { Relationshi } \\
p\end{array}$ & $\begin{array}{c}\text { Standar } \\
\text { d } \\
\text { Beta }\end{array}$ & $\begin{array}{c}\text { Standar } \\
\mathrm{d} \\
\text { Error }\end{array}$ & $\begin{array}{c}\text { t- } \\
\text { value }\end{array}$ & $\mathrm{Q}^{2}$ & $f^{2}$ & $\mathrm{R}^{2}$ & Results \\
\hline $\mathrm{H} 1$ & $\begin{array}{l}\text { Resource } \\
\text { Facilitating } \\
\text { Conditon -> } \\
\text { Perceived } \\
\text { Behavioural } \\
\text { Control }\end{array}$ & 0.190 & 0.052 & $\begin{array}{c}3.627 \\
* *\end{array}$ & $\begin{array}{l}0.36 \\
9\end{array}$ & $\begin{array}{l}0.05 \\
9\end{array}$ & $\begin{array}{l}0.58 \\
2\end{array}$ & $\begin{array}{c}\text { Supporte } \\
\text { d }\end{array}$ \\
\hline $\mathrm{H} 2$ & $\begin{array}{l}\text { Self-Efficacy } \\
-> \\
\text { Perceived } \\
\text { Behavioural } \\
\text { Control }\end{array}$ & 0.583 & 0.050 & $\begin{array}{c}11.73 \\
4 * *\end{array}$ & & $\begin{array}{l}0.56 \\
1\end{array}$ & & $\begin{array}{c}\text { Supporte } \\
\text { d }\end{array}$ \\
\hline $\mathrm{H} 3$ & $\begin{array}{l}\text { Financial } \\
\text { Literacy -> } \\
\text { Perceived } \\
\text { Behavioural } \\
\text { Control } \\
\end{array}$ & 0.148 & 0.044 & $\begin{array}{c}3.407 \\
* *\end{array}$ & & $\begin{array}{l}0.04 \\
7 \\
\end{array}$ & & $\begin{array}{c}\text { Supporte } \\
\text { d }\end{array}$ \\
\hline $\mathrm{H} 4$ & $\begin{array}{l}\text { Perceived } \\
\text { Behavioural } \\
\text { Control -> } \\
\text { Intention }\end{array}$ & 0.774 & 0.026 & $\begin{array}{l}30.19 \\
3 * *\end{array}$ & $\begin{array}{l}0.46 \\
9\end{array}$ & $\begin{array}{l}1.49 \\
6\end{array}$ & $\begin{array}{l}0.59 \\
9\end{array}$ & $\begin{array}{c}\text { Supporte } \\
\text { d }\end{array}$ \\
\hline
\end{tabular}

Notes: ${ }^{* *} p<0.01 ;{ }^{*} p<0.05$

\section{Conclusion}

This paper seeks to establish the relevance of financial literacy in the Decomposed Theory of Planned Behavior in the context of the purchase of unsought goods specifically life insurance or Takaful among Muslims. The decomposition of perceived behavioural control in this theory is extended to include financial literacy as it is postulated to be relevant in the context of unsought goods. The results validated the robustness of the Decomposed Theory of Planned Behavior to explain purchase intention of life insurance or Takaful. This result suggests that perceived behavioral control is affected by determinants of self-efficacy, resource facilitating condition, and financial literacy in the purchase of the identified unsought goods. The results indicated that once people have resources such as time, (i.e. resource facilitating condition) and the ability to perform the task (i.e. self-efficacy) and they know how to accumulate their wealth properly (i.e. financial literacy), it easier for them to participate in life insurance/Takaful. This result is in line with the previous studies (Aziz et al., 2017; Nasir et al., 2017; Nasir et al., 2020; Primabodi and Samopa, 2017; Susanto, 2013). Additionally, the significant influence of perceived behavioral control on intention is also found in this study which is similar to past studies (Kanimozhi and Sundar, 2017; Khasawneh and Irshaidat, 2017; Pratiwi and Hartoyo, 2014; Echchabi and Echchabi, 2013; Innan and Moustaghfir, 2012). It is accepted that selling and marketing unsought products 
in the market can be very challenging. As such, a critical analysis on new possible determinants like financial literacy is needed to further understand Muslims' behaviour in purchasing unsought products like life insurance/Takaful. Muslims are specifically given the attention in this paper as it is already established in the Al-Quran and Al-Hadith on the need to protect and prepare ourselves in the event of unanticipated predicament but this is often left unheeded. As such, this paper affirmed decomposed construct of financial literacy in relation to perceived behavioural control as the element that may well attract the purchase of unsought goods like life insurance/Takaful among Muslims.

\section{References}

Abdullah, I., \& Rashid, Y. (2014). Poverty, Conventional Insurance and Takaful: A Journalistic Review. Research Journal of Recent Sciences, 3(10), 108-112.

Ahmad, N., Harun, A., Rashid, N. K., Othman, B., Khizer, H. M. U., \& Khan, S. (2020). The effect of w-WOM, perceived value, trust on online consumer behavioral intention: Perspective of consumer from Pakistan. International Journal of Psychosocial Rehabilitation, 24(5), 77847796.

Ahmad, Z., Simun, M., \& Masuod, M. S. (2006). Determinants of financial behaviours among Malaysians, Indonesian Capital Market Review, 2(2), 121-132.

Ajzen, I. (1991). The theory of planned behavior. Organizational Behavior and Human Decision Processes, 50(2), 179-211.

Akgunduz, Y., Bardakoglu, O., \& Koba, Y. (2020). The effects of participant motivational behavioural intention: The MARBLE case. Tourism and Management Studies, 16(3), 15-22. Aksa, F. I. (2020). Islamic perspectives in disaster: An alternative to changing fatalistic attitudes. Jamba: Journal of Disaster Risk Studies, 12(1), a942.

Alalwan, A. A. (2020). Mobile food ordering apps: An empirical study of the factors affecting customer e-satisfaction and continued intention toreuse. International Journal of Information Management,50, 28-44.

Alharbi, S., \& Drew, S. (2014). Using the Technology Acceptance Model in understanding academics' behavioural intention to use learning management systems. International Journal of Advanced Computer Science and Applications, 5, 143-155.

Atsoglou, K. \& Jimoyiannis, A. (2012). Teachers' decisions to use ICT in classroom practice: An investigation based on decomposed theory of planned behavior. International Journal of Digital Literacy and Digital Competence, 3(2), 20-37.

Aziz, S., Husin, M., \& Hussin, N. (2017). Conceptual framework of factors determining intention towards the adoption of family takaful - An extension of decomposed theory of planned behaviour. International Journal of Organizational Leadership, 6, 385-399.

Bandura, A. (1986). Social Foundations of Thought and Action, Prentice-Hall, Eaglewood Cliffs, NJ.

Bhattacherjee, A. (2000). Acceptance of e-commerce services: The case of electronic brokerages. IEEE Transactions on Systems, Man, and Cybernetics-Part A: Systems and Humans, 30(4), 411-420.

Chin, W. W. (1998). The partial least squares approach for structural equation modeling. In: Marcoulides GA (ed) Modern methods for business research. Lawrence Erlbaum Associates London.

Chin, W. W. (2010). How to write up and report PLS analyses, in Vinzi, V.E., Chin, W.W., Henseler, 
J. and Wang, H. (Eds), Handbook of Partial Least Squares: Concepts, Methods and Applications in Marketing and Related Fields, Springer, Berlin, 655-690.

Cohen, J. (1988). Statistical power analysis for the behavioral sciences. Lawrence Erlbaum, Mahwah, New Jersey.

Daljit, D. (2011). More M\&As seen in insurance and takaful. The Star. Retrieved from http:www.thestar.com.my/business/business-news/2011/05/14/more-mas-seen-ininsurance-and-takaful/

Dom, N. C., Madzlan, M. F., Yusoff, S. N. N., Ahmad, A. H., Ismail, R., \& Camalxaman, S. N. (2016). Profile distribution of juvenile Aedes species in an urban area of Malaysia. Transactions of The Royal Society of Tropical Medicine and Hygiene, 110(4), 237-245.

Echchabi, A., \& Echchabi, F. (2013). Islamic insurance in the European countries: Insight from French Muslims' perspective. WSEAS Transactions on Business and Economics, 10(3), 125132.

Ghoni, A. (2016). Konsep Tawakal dan Relevansinya dengan Tujuan Pendidikan Islam: Studi komparasi mengenai konsep tawakal menurut M. Quraish Shihab dan Yunan Nasution. AnNuha: Jurnal Kajian Islam, Pendidikan, Budaya \& Social, 03(01).

Ghorbanzade, D., Mehrani, H., \& Rahehagh, A. (2019). The effect of experience quality on behavioral intentions of domestic tourists in visiting water parks. Cogent Business \& Management, 6, 1-24.

Hair, J. F. J., Hult, G. T. M., Ringle, C. M., \& Sarstedt, M. (2017). A Primer on Partial Least Squares Structural Equation Modeling (PLS-SEM), 2nd ed., Sage, Thousand Oaks, CA.

Hair, J. F., Ringle, C. M., \& Sarstedt, M. (2011). PLS-SEM: Indeed a silver bullet. Journal of Marketing Theory and Practice, 19(2), 139-151.

Husin, M. H., \& Rahman, A. A. (2016). Do Muslims intend to participate in Islamic insurance?Analysis from theory of planned behaviour. Journal of Islamic Accounting and Business Research, 7(1), 42-58.

Husin, M. H., Ismail, N., \& Rahman, A. A. (2016). The roles of mass media, word of mouth and subjective norm in family takaful purchase intention. Journal of Islamic Marketing, 7(1), 59-73.

Innan, R., \& Moustaghfir, K. (2012). Predicting employees' behaviour: An application of the theory of planned behaviour: The case of the Moroccan Forestry Department( HCEFLCD). In Proceedings of the Management, Knowledge and Learning International Conference 2012.

Kaligis, F., Indraswari, M. T., \& Ismail, R. I. (2020). Stress during COVID-19 pandemic: mental health condition in Indonesia. Medical Journal of Indonesia, 1-6.

Kanimozhi, S. \& Sundar, S. (2017). Adoption of 4G mobile services in India: An explanation through decomposed theory of planned behaviour. Journal of Emerging Technologies and Innovative Research (JETIR), 4(11), 23-27.

Khalid, M. N., \& John, M. P. (2008). An Exploratory study into the adoption of internet banking in a developing country: Malaysia. Journal of Internet Commerce, 7(1), 29-73.

Khan, A., \& Azam, M. K. (2016). Factors influencing halal products purchase intention in India: Preliminary Investigation. The IUP Journal of Marketing Management, 15(1), 20-35.

Khasawneh, M. H. A., \& Irshaidat, R. (2017). Empirical validation of the decomposed theory of planned behaviour model within the mobile banking adoption context. International 
INTERNATIONAL JOURNAL OF ACADEMIC RESEARCH ECONOMICS AND MANAGEMENT SCIENCES

Vol. 10, No. 1, 2021, E-ISSN: 2226-3624 @ 2021 HRMARS

Journal of Electronic Marketing and Retailing, 8(1), 58-76.

Lada, S., Tanakinjal, G. H., \& Amin, H. (2009). Predicting intention to choose halal products using theory of reasoned action. International Journal of Islamic and Middle Eastern Finance and Management, 2(1), 66-76.

Lau, A. (2011). Hospital-based nurses' perceptions of the adoption of web 2.0 tools for knowledge sharing, learning, social interaction and the production of collective intelligence. Journal of Medical Internet Research, 13(4), e92.

Leejoeiwara, B. (2013). Modeling adoption intention of online education in Thailand using the extended decomposed theory of planned behavior (DTPB) with self-directed learning. AU Journal of Management, 11(2), 13-26.

Macredie, R. D., \& Mijinyawa, K. (2011). A theory-grounded framework of Open Source Software adoption in SMEs. European Journal of Informations Systems, 20(2), 237-250.

Madden, T. J., Ellen, P. S., \& Ajzen, I. (1992). A comparison of the theory of planned behaviour and theory of reasoned action. Personality and Social Psychology Bulletin, 18(3), 3-9.

Mahdzan, N., \& Victorian, S. (2013). The determinants of life insurance demand: A focus on saving motives and financial literacy. Asian Social Science, 9(5), 274-284.

Matsawali, M. S., Abdullah, M. F., Yeo, C. P., Abidin, S. Y., Zaini, M. M., Ali, H. M., \& Yaacob, H. (2012). A study on Takaful and conventional insurance preferences: The case of Brunei. International Journal of Business and Social Science, 3(22), 163-176.

Megatsari, H., Laksono, A. D., Ibad, M., Herwanto, Y. T., Sarweni, K. P., Geno, R. A. P., \& Nugraheni, E. (2020). The community psychosocial burden during the COVID-19 pandemic in Indonesia. Heliyon, 6(10), e05136.

Mtebe, J. S., \& Raisamo, R. (2014). Investigating students' behavioural intention to adopt and use mobile learning in higher education in East African. International Journal of Education and Development using Information and Communication Technology (IJEDICT), 10(3), 4-20.

Mustafa, F. H., \& Bagul, A. H. B. P. (2020). The impact of coronavirus on the tourism sector with special reference to Malaysia. Labuan Bulletin of International Business \& Finance, 18(1), 75-83.

Nasir, N. F., Roslin, R. M., \& Chui, T. B. (2020). An extended analysis of Muslims' behavioral intention in purchasing unsought products. International Research Journal of Modernization in Engineering Technology and Science, 2(11), 164-178.

Nasir, N. F., Roslin, R. M., \& Chui, C. B. (2017). Decomposing the theory of planned behaviour and incorporating spiritual intelligence to further understand purchase intention of life insurance and Takaful. International Journal of Economic Research, 14(6), 241-252.

Oladapo, I. A., Omar, N., Muda, R., \& Abdurraheem, A. A. (2019). The mediating effect of attitude on customers' behavioural intention to participate in Islamic banking: Empirical evidence. International Journal of Financial Research,10(5), 167-180.

Omar, O. E. (2007). The retailing of life insurance in Nigeria: An assessment of consumers' attitudes. The Journal of Retail Marketing Management Research, 1(1), 41-47.

Potrich, A. C., Vieira, K. M., \& Mendes-Da-Silva, W. (2016). Development of a financial literacy model for university students. Management Research Review, 39(3), 356-376.

Prasetyo, Y., \& Absori, A. (2018). Convergenceepistemologies of legal studies perspectives of Islamic philosophy. Millati: Journal of Islamic Studies and Humanities, 3(1), 1-27.

Pratiwi, N., \& Hartoyo, H. (2014). Analisis niat beli asuransi jiwa pada mahasiswa: Aplikasi theory 
of planned behavior. Jurnal Ilmu Keluarga dan Konsumen, 7(1), 58-66.

Primabudi, A. M., \& Samopa, F. (2017). Analysis of factors influencing purchase decision in online store. Case Study: Game sales in online store. International Journal of Education and Research, 5(7), 277-288.

Qader, I., \& Zainuddin, Y. (2011). The impact of media exposure on intention to purchase green electronic products amongst lecturers. International Journal of Business and Management, 6(3), 241-248.

Santos, L. M. R. D., \& Okazaki, S. (2013). Understanding E-Learning adoption among Brazilian universities: An application of the decomposed theory of planned behavior. Journal of Educational Computing Research, 49(3), 363-379.

Sukiman (2017). The thoughts of Syah Wali Allah Ad-Dahlawi about tauhid as the foundation of development. Global Journal of Arts, Humanities and Social Sciences, 5(4), 59-68.

Susanto, T. D. (2013). Individual acceptance of e-government: A literature review. The Second International Conference on Informetics Engineering \& Information Science (ICIES2013). The Society of Digital Information and Wireless Communication, 334-342.

Susanto, T. D. \& Goodwin, R. (2013). User Acceptance of SMS-based e-government services: Differences between adopters and non-adopters. Government Information Quarterly, 30(4),486- 497.

Taylor, S., \& Todd, P. (1995). Decomposition and crossover effects in the theory of planned behavior: A adoption intentions. International Journal of Research in Marketing, 12(2), 137155.

Teo, T. S. H., Srivastava, S. C., \& Jiang, L. (2008). Trust and electronic government success: an empirical study. Journal of Management Information Systems, 25(3), 99-132.

Triandis, H. C. (1980). Values, Attitudes, and Interpersonal Behaviour", Nebraska Symposium on Motivation, University of Nebraska Press, Lincoln.

Tsai, W. C. (2012). A study of consumer behavioral intention to use e-book: the Technology Acceptance Model perspective. Innovative Marketing, 8(4), 55-66.

Zakub, R., Widodo, S. T., \& Setiawan, B. (2018). The relevance between Javanese pitutur luhur and Islam religiosity. IBDA : Jurnal Kajian Islam Dan Budaya, 16(1), 148-164. 